\title{
The distortion of beliefs in the face of uncertainty
}

\author{
Lennart Sjöberg \\ Department of Psychology, \\ Norwegian University of Science and Technology, \\ 7491 Trondheim, Norway \\ E-mail: andeca@fastmail.us
}

\begin{abstract}
Judgements and beliefs often are distorted. They are affected by underlying values and reflect strong tendencies toward wishful thinking. In action, biased thinking may or may not be detrimental, and there is a very delicate balance to keep between the need to motivate oneself for forceful action, and to keep a realistic view of the possibilities of success. People encounter problems, calling for thought and the formation of constructs, only rather rarely, but when they do they tend to be in an unpleasant emotional state. Uncertainty is one such state, in which one encounters difficult problems and expects little success.
\end{abstract}

Keywords: thought biases; heuristics; judgement; decision making.

Reference to this paper should be made as follows: Sjöberg, L. (2007) 'The distortion of beliefs in the face of uncertainty', Int. J. Management and Decision Making, Vol. 8, No. 1, pp.1-29.

Biographical notes: Lennart Sjöberg has a $\mathrm{PhD}$ in Psychology from the University of Stockholm. He was a visiting Professor at UC Berkeley and Stanford University, is a member of the Royal Swedish Academy of Engineering Sciences. He is currently Adjunct Professor of Community Psychology at the Norwegian University of Science and Technology, Trondheim, Norway. He was Professor of Psychology at the Stockholm School of Economics and Head of its Center for Risk Research, a Fellow of the Society for Risk Analysis and a member of the Editorial Board of Journal of Risk Research, International Journal of Risk Assessment and Management, Risk Analysis and European Psychologist. He is working on perceived risks of gene technology, and nuclear waste as well as emotional intelligence.

\section{Introduction}

What is a rational way to act in everyday life, and how rational are people? How do they process information? Could it be done in a better way? Is education of any help? These are some of the questions I will discuss in the present paper. The review will build largely on work in our own unit and there will of course be no attempt to cover all the interesting and important topics in full. Rather, the purpose is to throw some light on phenomena, concepts and results in a perspective which may be different from the usual ones, and point to interesting questions for further research.

The problems I discuss pertain both to decision making and to information processing in a more general sense. Information is gathered in order to inform the decision making 
process. Information acquisition is by itself a process where decisions are made, e.g., about stopping or continuing the process. The various limitations on human functioning that form the topic of the present paper affect both information acquisition and decision making proper.

Although business and other on-the-job decisions are the field of application I have in mind, much of the discussion will be more general. There is no reason to believe that business decisions are much different from other types of decisions.

Many decisions must be taken in the face of uncertainty. The dominant way of dealing with uncertainty is to use the concepts of probability and randomness. Even if a richly developed concept of chance and probability is lacking in some cultures, it is reasonable to believe that people must always have wrestled with uncertainty and constructed various concepts to deal with a very basic predicament of the human condition: that life is full of uncertainty.

I therefore begin with a discussion randomness and probability and then go on to a section covering the limitations of human information processing.

\section{The nature of uncertainty and randomness}

Probability is a very important concept in all of science, certainly including social and behavioural science. It is also a very important concept in everyday thinking, and we often talk about chance or random events, especially when they were unexpected and worked to our advantage or its opposite. In psychology, attribution theory (Ross and Fletcher, 1985) and the theory of locus of control (Lefcourt, 1976) are well-known examples of conceptual systems in which chance plays an important role. In Cultural Theory of risk perception (Douglas and Wildavsky, 1982), to take another example, fatalism is one of the postulated world views alleged to be of great importance in structuring risk perception.

But what does it mean to say that an event is truly a chance or random event? I propose that it means that there are no causes to the event so it could not have been predicted, nor can it be explained. Do such events happen - except possibly in the world of particle physics? ${ }^{1}$ Let us look at how we talk about randomness when using natural language. Two examples may illustrate the point I wish to make.

- I throw a die and it comes to rest with six on the side facing me.

- On a recent trip from Spain, I happened to be seated next to a lady who had a severe flu. I caught the same illness (I think).

The first example is commonly used in discussions of probability. If the die is fair its behaviour will be well modelled by probability calculus which in turn assumes that the result of each throw of the die is a chance event. But, upon reflection, we have to concede that the outcome would in principle be perfectly predictable, i.e., given full knowledge of all the pertinent parameters of a throw, spatial relations (distance to the table etc), elasticity of the die and so on, we could, by using relatively simple physical theory predict the outcome of any throw. In practice it would be unlikely that we could measure all these variables, or would bother to do so. But the principle is clear enough, and convincing. The fact that probability calculus fits well to the behaviour of the die reflects certain abstract properties of the determining factors, they are many and more or less 
independent. Note that calculus is not concerned with predicting the behaviour of any one throw, but with properties of distributions of outcomes over many throws. The larger the number of throws studied, the better will these distributions conform to the laws of probability calculus. However, this does not justify the conclusion that any throw of the die is a strict chance event. As we have seen, it is completely determined by a number of physical factors.

The second example is one of coincidence. Ms. X, who gave me her flu, was certainly not behaving randomly and neither was I. The fact that we were seated next to each other by the airline personnel was also not random, but followed the logic of their work, whatever it is (one sometimes wonders). They did not know that they exposed me to a risk, nor would they have cared if they had known. Given a fully booked flight, why should one passenger be protected at the expense of another? Yet, the constellation of these factors, i.e., my behaviour, Ms. X's behaviour and the behaviour of the airline personnel, was instrumental in having a significant negative effect. Our lives are full with such coincidences, some negative and some positive. We talk about them as chance events, but on reflection we have to concede that they are not strictly random events. They have their determining factors, their causes. It is the constellation of these events which is the critical aspect and we attribute randomness to the whole event because the critical aspects of it seem unrelated. We cannot see a Grand Plan behind events such as these unless we are paranoics who embrace a conspiracy theory, or fundamentalist religious people who see a Higher Meaning mysteriously engineered by God, in all that happens. Or maybe some 'evil force' was behind it? Or what Strindberg called 'makterna', The Powers? The question of Meaning rises on the horizon.

\section{$2.1 \quad$ Meaning}

There is a strong quest for finding a meaning in all significant events, maybe especially when they are disastrous. Sometimes such a quest turns into a never-ending story. Consider the death of Sweden's great Warrior King, Charles XII, in 1718 (Hatton, 1968; Liljegren, 2000). The debate still rages about what really happened. Several home pages on the world wide web discuss it, and historians seem keen on publishing new books and papers on the topic.

On 30th November 1718 Charles, waging war against Denmark and Norway, found himself in a trench in the vicinity of the Norwegian fortress of Fredrikshald. The Swedes were besieging that Norwegian stronghold. Charles was hit by a bullet which went through his head and killed him immediately, an event which had momentous consequences because the Swedes gave up their attempt at invading Norway and a new Constitution was to follow in Sweden, royal authoritarian rule being replaced by a Parliamentary system.

Was this a chance event, a stray bullet fired from the fortress (such bullets were fired in great frequency), or was it murder, by someone there close to the King, in the trench? Rumors about murder started immediately and they are still discussed. Different historical theories have been discussed during the soon 300 years that have gone by, and at the present the Stray Bullet Theory seems to be dominating. However, a momentous event such as this must have a less trivial cause, must it not? We refuse to believe that very important events can have trivial causes. If you look carefully, you can most of the time find a lot to build your case of a significant cause. This is surely true also for the death of Charles. 
In fact, Charles had been a disaster for Sweden, having lost a war against Russia and that war and his many other military adventures had been very costly. His attitude grew increasingly rigid over time. The wars just went on and on. Many people must have wanted peace, and his replacement by someone more flexible, and the end of authoritarian rule. His brother in law, Prince Fredrik of Hessen, had formed an opposition group and Fredrik secretly aspired to become Charles's successor. ${ }^{2}$ But Charles was fairly young and could live for many years still. What would be more natural than murder and a coup d'état? Historians have found some evidence that such a plan was in the making - but maybe 'chance' intervened and they did not have to carry out their plans. The clues are many and as the years go by, they seem to multiply. And as in many other cases like this, several people confessed to having been the assassin.

The interesting thing about this case is that it illustrates how there may be potential meanings which can be disclosed and believed to be the real meanings of events that possibly had very different causes of the 'chance' kind. Examples in modern times are many: the assassination of John F. Kennedy in 1963 and Swedens' Prime Minister Olof Palme in 1986 immediately come to mind. Though nobody argues that they were not murdered it is still impossible to reach social consensus about who was the ultimate force behind the events, or even who was the killer. Exit Meaning, enter Responsibility.

\subsection{Responsibility}

The idea of chance events seems to arise when otherwise independent chains of events 'collide', as it were. But what does it mean to say that they are 'otherwise independent'? I suggest to explicate this concept on the basis of intentions, or plans. A chain of events is structured as a Gestalt, or meaningful pattern, given that it can be traced to a plan by some actor. The actor can be an individual, a group, or an organisation. When Ms. X decided to get on that aircraft, and the airline people seated us next to each other, her plan had absolutely nothing to do with my, parallel, plan to travel from Malaga to Stockholm. We had never before met, and probably will never meet again. I do not know her name, or anything else about her. As a person she is indifferent to me, except as a carrier of a virus that gave me a miserable Christmas holiday. I bear no grudge against Ms. X, however, because I am sure she did not intend that to happen. Even though she must have known that she exposed other people to a moderately nasty risk, I do not feel it would have been reasonable to demand that she should have abstained from travelling. The risk was moderate and it is not, in our culture, demanded that we protect our fellow human beings from such a risk. It is different in other countries. In Japan, people wear special masks when they are infected with a flu virus, in order to warn others and to diminish the risk of spreading the virus to them. However, I have never seen anyone wearing such a mask (outside a hospital) in Sweden or in Western Europe at large, and quite possibly, wearing one would be considered to be weird or even threatening. I am not even sure that an airline in Western Europe would accept a passenger who wanted to wear a mask.

If events are seen as caused by actors, there is a question of responsibility. Maybe even the lowly messenger of (bad) tidings will be held responsible, and summarily executed to mitigate the wrath of the Monarch whose defeat he reported. Everybody realises that such treatment of messengers is unfair, but just the same we dislike those who predict failure, and when it turns out they were right, we attribute that very failure to those ominous Cassandras. The prediction of positive outcomes may well contribute to optimism and stamina, making the positive prophesies self fulfilling. 


\subsection{Much talk about randomness, not seriously intended}

There is much double talk about chance and randomness. The terms are used very frequently but perhaps without a serious intention to assert that things are truly random. Maybe it just seems pointless to talk about the factors that gave rise to collisions of independent plans, even if such factors could in principle be specified and maybe even measured in some cases. They would have little systematic interest - the collisions just happen for a multitude of particular reasons which have no inherent or otherwise significant meaning - to all who are not inclined to construe paranoid systems of interpretation. The example of the death of Charles XII shows what is possibly a typical wealth of possible 'meaningful' interpretations of what may well have been the effects of a stray bullet - in itself not random but that shot was possibly just fired in ignorance that its target may have been of momentous importance. (Who expected the King of Sweden to be exposed to enemy fire at that particular time and place? ... Well, he was known for his daredevil attitude to such risks, so maybe there were some hopeful artillery officers on the Norwegian side who thought about the possibility...). The assassination of John F. Kennedy is perhaps even more illustrative, since there has been so much more written about it and so many people have tried out various clues to what really happened that fateful day in Dallas. Marrs's book 'Crossfire. The plot that killed Kennedy' (Marrs, 1989) gives many examples of events surrounding the assassination, events which may be construed as 'evidence' of a plot. Oliver Stone's movie 'JFK' was inspired by the book, but is interesting also because it freely adds pieces of 'evidence' that have no support in reality whatsoever, they were just made up by the film makers. The example illustrates how fuzzy the border may be between more or less far fetched interpretations of reality, and pure phantasy.

\subsection{Hypothesis testing}

Even if most people believe that everything has a cause, however 'unrelated' or 'arbitrary', things seem to be different when it comes to the persuasive logic of statistical hypothesis testing. The idea behind such testing is simple enough. A model is construed, which allows an estimate to be made of the probability that a certain empirical result would have been obtained by pure chance, provided that there was exactly a nil relationship between two variables or exactly no difference between two conditions or treatments. In many cases, it turns out to be quite easy to establish that randomness is an implausible explanation of the findings. This is so because even moderately small samples allow for such a conclusion. Correlation coefficients between 0.05 and 0.10 , very weak relationships indeed, easily take on the glory of statistical 'significance'. Researchers have for half a century been trained to pay attention to little more than 'levels of significance'. The popularity of this paradigm of data analysis is probably due to the ease whereby statistical significance is established. If a statistically significant result is established, the researcher has taken a large step towards publication of his or her findings, and in narrative literature surveys, or textbooks, the question of size of difference or strength of relationship is rarely raised.

Significance testing as a methodological canon is likely to lead researchers astray because it is easy to obtain 'significant' results which may be quite trivial. Small effects are always likely to occur, and they can be established as significant if samples are large enough. Significance testing leads in the long run to divergence of a research field rather 
than convergence; a kind of 'hunchology' is developed. Many researchers enter the field, eager to establish a niche for original twists of the problems, and such twists can be developed in very large numbers. The field of research becomes unwieldy and very difficult to summarise in a succinct manner. The few important variables are not easily spotted unless researchers establish effect sizes and require that new hunches must be established as really contributing something of importance in addition to what is already known. Attitude research is a good example (Eagley and Chaiken, 1993).

\subsection{Probability calculus as a model for strength of belief}

The successful analysis of well-defined 'chance events', such as the successive throws of a die, have inspired many thinkers to conclude that probability calculus should be applied also to strength of belief, equating it with 'subjective probability' (Ramsey, 1931). It is the argued that subjective probability should follow the theorems implied by probability calculus, and Tversky and Kahneman showed that it frequently does not (Kahneman and Tversky, 1984). For example, if I am asked to rate my strength of belief that a person is a clinical psychologist rather than a bank clerk, and given the information that she likes to read books by Freud, I tend to believe that she is a clinical psychologist. However, there are many more bank clerks than clinical psychologists, so I thereby commit the error of disregarding the base rates of bank clerks and clinical psychologists. This conclusion is in one sense correct, given the initial assumption that strength of belief should be equated with subjective probability which in turn should follow the implications of probability calculus, in this case Bayes' theorem. But is that so obvious?

Strength of belief can be expressed in many ways. One of them, perhaps one which is neither obvious nor particularly good, is to ask people to rate the probability that a statement about a belief is true. It would be more natural to ask people to simply rate how strongly they believe in something. The Tversky-Kahneman paradigm of research on strength of belief derives its whole impetus from equating strength of belief with subjective probability and the use of probability calculus as a normative model used to assess the ratings of probability that people give. If the connection between strength of belief and subjective probability is not accepted, the whole paradigm loses a crucial element and even becomes almost pointless. Because why should probability calculus be taken as a normative model for strength of belief?

It could perhaps be argued that such a normative approach is pertinent because people must indeed adjust their strengths of belief to realities and realities are specified by calculus. That argument presupposes that the events that the beliefs refer to can be modelled well by probability, just as the successive throws of a die can be so modelled. Let us look at an example in diagnostic work.

A psychiatrist, used to work with severely ill patients, many of them diagnosed as schizophrenics, is doing his military service in the Army. There, it is his job to assess the mental status of conscripts and he is expected to detect, among other things, cases of severe mental illness, since such conscripts should be exempted from military service and possibly referred to a more thorough examination. He now meets with a conscript who confides in him that he sometimes has had mildly threatening auditory hallucinations. The psychiatrist concludes that this person may be severely ill, and hence he is exempted from military service and referred to a more thorough examination. From the standpoint of probability calculus, the psychiatrist is surely wrong in forming a relatively strong belief that the person is mentally severely ill. The reason is that in the general 
population there are only few such persons. Even if the diagnostic sign works well in the psychiatrist's daily work with a population of mentally ill patients, there is no guarantee that the sign will be at all valid in the general population. Some experience with auditory hallucinations is fairly common among people in general and is no sure sign of schizophrenia. Indeed, given only the basis of this particular 'symptom' (and maybe a few others) it is overwhelmingly likely, according to Bayes theorem, that the person is mentally sound.

The reason that the symptom is so persuasive is that we seldom think in terms of arbitrary and coincidental events, but in terms of causes and meanings. The fact that the psychiatrist met with the person during military enlistment seems just arbitrary and irrelevant to him (and to most other people). The correct judgement from the point of view of probability calculus carries little weight as long as it is disconnected from causal and meaningful structures. Many errors of judgement have their basis not so much in lack of cognitive capacity as in strong habits of thought, which involve the application of beliefs about causes, and the construction of meaning. We need to have this in mind when surveying work on judgement, the next major section of the present paper.

\section{Judgement and action}

\subsection{Judgement errors and cognitive limitations}

It has been clear for quite a long time that people have severe cognitive limitations (Dawes, 1988). Only 5-10 pieces of information can be held in short term memory at the same time (Miller, 1956; Cooksey, 1996). Our memories are quite imperfect and we can easily come to believe that something happened which, in fact, did not (Neisser and Harsch, 1992; Schacter, 1999). Experts in many fields have a belief that they can perform 'holistic' judgements, but no evidence supports such a claim (Ruscio, 2002). In forensic applications, witness psychologists have known for at least a century that eye-witness identification is highly uncertain, and that is true even if the witness him - or herself is ' $100 \%$ sure' (Cutler and Penrod, 1995). The naive belief that one can readily tell a lie from a true statement has again and again been proven false (Ekman and O'Sullivan, 1991). Decisions are rarely rational as they are assumed to be in economic theory; the assumption can only be retained in the face of a wealth of contrary data if strong ad hoc assumptions are made (Kahneman, 2000).

Faced with the bewildering complexity of the real world, people have to use ways of simplifying their judgement tasks. Some methods they use have been termed heuristics (Tversky and Kahneman, 1974). ${ }^{3}$ Kahneman and Tversky did the basic work on heuristics in the 1970s and found, in particular, that people often make gross errors when judging probabilities, as compared to the correct answer derived from probability calculus. The ecological validity of this research has been questioned (Gigerenzer, 1996), but there is some support for it (McNeil et al., 1982; Camerer, 2000). In related work, it was also found that people tend to be over-confident of their judgements, even if the generality of that statement is debated (Gigerenzer et al., 1991). In particular, experts tend to be even more over-confident than non-experts. They experience less uncertainty than what is justified.

Critical voices against this work have been many, see e.g., Berkeley and Humphreys (1982) and Anderson (1996), but it can safely be said that it does catch an important 
kernel of truth. It is unclear if people can and should, be trained to make judgements that are less likely to be affected by these simplifying strategies and other biasing factor (Mele, 1994). One difficulty is the tendency for biases to be domain-specific (Sa et al., 1999).

Even if the heuristics work is of value, a critical word is in place. It was for a while believed that it was very relevant to understanding how people perceive risks (Sjöberg, 1979), probably because it was about subjective probability and perceived risk seemed to be an example of subjective probability. The problem here is that risk, in real world applications to policy problems, probably is more a question of attitude than anything else (Sjöberg, 2000b) and it is not very helpful to approach it from the point of view of distortions of subjective probabilities due to cognitive limitations. People can hardly be 'educated' to have other risk perceptions than the ones they have.

Judgement errors are thus very common and the human predicament is that our cognitive powers are limited. But there is error and error. What could be called pathologies of judgement constitute a higher level of delusions and are also very common; here we deal with gross distortions of reality.

\subsection{Pathologies of judgement: superstition}

Superstition has its traditional and its modern forms, the latter often summarised under the heading New Age. I have investigated such beliefs in some depth (Sjöberg and af Wåhlberg, 2002) and found that they are negatively related to educational level and positively to maladjustment, but you can indeed find them all over society. I investigated the relationship between various superstitious beliefs and risk perception and found that about $15 \%$ of the variance of risk perception could be explained by superstition. One can only speculate about the direction of influence here. Do these concepts have a common ground, e.g., in feelings of low self-efficacy? It has been suggested that the need for control and understanding is a powerful determinant of superstition (Lindeman, 1998).

Vyse (1997) emphasised 'learning', in the Skinnerian tradition of behavioural analysis of superstition (Skinner, 1948). For example, sport stars often seem to believe that lucky charms, and certain kinds of behaviour before a game, are very important to success. Perhaps such behaviour is related to the great uncertainty in sports, where so much is dependent upon finely tuned integration of movement and timing, and where there is fierce competition from very skilled and highly motivated opponents.

However, this sounds like a description of the situation for many businessmen. Does business uncertainty also lead to superstitious behaviour - and if not, why not? Are the conditions for business success very different from those in sports? It would be interesting to know more about superstition and other grossly derelict forms of beliefs in business. Superstitious beliefs need not be entirely destructive, by the way, since they may contribute to optimism which, although unjustified to begin with, tends to work as a self-fulfilling prophecy (Taylor and Brown, 1988). The fashionable business 'cults' of various management fads may have this very function and serve it well, in spite of being out of touch with scientific research (Furusten, 1996).

Wishful thinking is notorious in leading us astray, many examples could be cited. Babad found, for example, that voters exhibited very strong wishful thinking, which was little affected by the promise of incentives for correct predictions of the outcome of elections (Babad, 1997), nor by knowledge (Babad, 1995) or the prospect of financial loss in betting (Babad and Katz, 1991). Another example is that of the very common 
problems in business in project planning. Projects very often are seriously delayed and cost much more than anticipated (Sjöberg and Pirie, 1999a, 1999b). The reasons are of course many, but one important factor is that of human thought habits. Another example concerns decision making on credit applications. Banks need to screen out optimistic realists from wishful thinkers, and how to do that is no easy problem to solve (Manove and Padilla, 1999). Assessment of business risk is thus important in order to promote realism and take preventive action in time (Simons, 1999).

Self-deception is a question of motivational and cognitive dynamics and not to be equated with fraudulent deception of others (Mele, 1997). The question whether it is purely cognitive or not is unsettled, see Metcalfe (1998) for a cognitive argument. Gilovich pointed out that wishful thinking and other cognitive illusions cannot be totally dominant since we, most of the time, relate to the world in a reasonably efficient manner (Gilovich, 1991, 1997). This is true, when it comes to the world as it exists in the overt sense.

However, many of our transactions are not with the overt world but with less transparent dimensions which may be termed the covert world. The covert world may exist here and now or it may be the world of the future. For example, the mental life of other people are covert to us, yet may be of paramount importance. The future is by definition known only through guesses or inferences. In both cases we deal with guesses and probabilities and the mistakes we make and the wishful thoughts we entertain are less likely to be given immediate negative feedback. It is in our dealings with the subtle properties of the covert world and the not yet existing world that we can become victims of inappropriate thought habits, and the results may be just as disastrous as if we close our eyes to existing realities.

Rationality cannot be fully understood without an analysis of action, and of volition, the topic of next section. ${ }^{4}$

\section{Volition and interest}

Somewhere around the beginning of the 20th Century, psychology lost contact with a basic phenomenological reality: volition. The reasons were probably a general suspicion of mentalistic concepts but also that this particular concept was associated with some philosophical schools that were in disrepute. In addition, psychology of the time embraced simple mechanistic explanations of 'behaviour' being a function of 'stimuli', and such explanations were seemingly amenable to a reductionistic analysis in physiological terms. When the discipline woke up from this behaviouristic nightmare, volition was among the last of the major phenomenological constructs to be again considered worthy of scientific study. All this said as an explanation of the paucity of studies of volitional phenomena.

Yet, it is obvious that phenomena of volition are of great importance in everyday life. People act on their intentions, and they sometimes fail, sometimes succeed. Part of the reason for their success can be sought in how realistic a view of the world they have, and how accurate their judgements are, but only part. It is not enough to make the right decision, you must also act on it, and sustain your action in the face of such difficulties as tiredness, temptations and various unforeseen problems (Sjöberg, 1980). To do so you need most of all a very strong will to carry through, and a strong interest in the activity. 
Interest is normally the basis of volitional action since we tend to follow our interests, impulses and desires. Sometimes, things are different and we need to use 'will power' to carry through an action. This may be productive in the short run and with routine tasks but it is hardly a fruitful basis for creative action or long-term success.

Interest is a crucial factor in learning, at least if there is goal to promote creativity (Ackerman and Heggestad, 1997; Sjöberg, 1997; Sjöberg and Dahlstrand, 1987). Interest is becoming more and more central to our understanding of business success (Delmar, 1996; Vinchur et al., 1998). It is interest that keeps the lamp burning well after midnight and people at work also on weekends. Interest is the fuel which keeps the fire of creative thought burning. This is especially true when the structural conditions make a net economic profit from hard work unlikely.

Action is dynamically integrated with judgement, and the net outcome of acting and judging is a function of their interplay. So far, I have focused on action but now I turn to a closer scrutiny of the properties of judgement.

\section{Science vs. subjective judgement}

Science is about finding out how the world is really constituted. In other words, Truth. Of course, the naive conception of truth that it can be achieved once and for all, is rarely subscribed to, when it comes to empirical science, since a multitude of interpretations are almost always possible and few believe that the Ultimate and Final Truth is ever achievable. Yet, science does succeed in achieving a better and better understanding of the world, which includes, but does not preempt, providing us with better and better means for manipulating it, for good or for bad purposes.

In an era of science, such as the present one, it is easily forgotten that there are many kinds of knowledge besides the scientific one. These other kinds of knowledge will be briefly discussed here. In particular, I deal with the everyday knowledge of businessmen - with their experience and with their beliefs. These beliefs monitor their actions in general and their plans and uncertainties in particular. I will focus on knowledge rather than understanding, the latter term referring to a feeling of knowledge, which may or may not be substantiated. Such feelings are common and many times misleading, as we shall see.

A few psychologists started about 50 years ago to interest themselves in what they called (and still call) 'clinical' judgement. This term is somewhat unfortunate since it suggests that the phenomenon under study is more specific than it really is. What is really at stake is the validity of subjective human judgement of complex phenomena and conditions, i.e., of the trials and tribulations of everyday life.

$\mathrm{Be}$ that as it may, the first major work in this area was concerned with clinical judgement in the true sense of the word, with judgements made by clinical psychologists and psychiatrists. These people made, and still make, a large number of assessments of various kinds of important issues. A psychiatrist may, e.g., be called upon to judge the likelihood that a prison inmate, upon parole, will commit crimes of violence. Such judgements are notoriously fallible, see Bonta et al. (1998).

Meehl, in his seminal study, found that clinical judgements almost invariably were worse than a simple statistical equation based on the same data - or even on less data (Meehl, 1954). This finding has now been many times replicated in virtually all fields of expert human judgement (Grove and Meehl, 1996; Grove et al., 2000). It has even been 
found that human judges, including experts, are outperformed by models of their own judgements (Goldberg, 1970). The reason is probably that human judges are inconsistent in the sense that they tend to make different judgements, given the same information. They add an element of random error to the judgements.

Many studies of this issue have been carried out and few do not confirm Meehls original findings. It is simply not possible to support the frequent claims that experts can utilise complex patterns of information, or are sensitive to idiosyncratic conditions that make a general rule inapplicable. They still cannot outperform simple statistical models of the data, and frequently even make worse predictions with more data than the models. That is, they make things worse, and they do so quite often for a substantial fee. That anybody is willing to pay for such degradation of information is remarkable and another testimony to the fallibility of human judgement.

Dawes has written a brilliant book which describes, in detail, the shortcomings of judgements by clinical psychologists and psychiatrists (Dawes, 1994); some more recent work is covered by Garb (1998). However interesting these findings may be, they leave something to be desired when it comes to many important applications of expert judgements. Businessmen are experts, or at least they strive to be and some of them actually are. Judgement errors are no doubt found in business, e.g., in the stock market. A penetrating analysis of the stock market situation in the end of the 1990s was provided by Shiller (2000), see also Shefrin (1999). In a financial bubble, more and more people are attracted to speculate when they have learned about the spectacular gains made by the previous wave of investors, and they are less and less competent for each new wave. In the final stage, a few superficial cues seem to suffice to attract these investors - until the bubble bursts because there are no new waves of capital available for investment, hence no more price increases. The psychology of the stockmarket is only now being opened up as a field of research on a large scale (Sjöberg, 2002a; Wärneryd, 2001).

The IT-bubble in 1999-2000 provides interesting examples of these phenomena. One of the earliest, and biggest, crashes occurred in May 2000 when boo.com, a sports and fashion online retailer, went bankrupt (Sjöberg, 2002b). The story of boo.com has been told by one of its founders, Malmsten et al. (2001) and by Lindstedt (2001). The case has several interesting angles and wishful thinking was clearly present in the initial stages of building up this firm on the basis of inflated beliefs about how easy it would be to sell up-market fashion clothes on the internet. It should also be noted that expertise on all aspects of online retailing simply did not exist at that early point, simply because the technology had not been available earlier.

Are all experts worse than simple statistical models? It has been found that some experts do quite well (Ericsson and Charness, 1994; Ericsson and Smith, 1991; Shanteau, 1988, 1992a, 1992b; Shanteau and Stewart, 1992). In cases where there is rapid and clear feedback and a good theory on which to base one's judgements, experts may actually develop a very efficient mode of judgement. Yet, these conditions are rarely at hand in business. In business, feedback is many times slow and hard to interpret and there is no good theory on which to base judgements. Hence, most judgement in business appears to be of the kind that can be beaten easily by statistical models, provided that appropriate input to the models can be obtained. (Experts may have a function in knowing just what input to enter in the models).

Thus, subjective judgements of all kinds, including most expert judgements, do not fare well when compared with systematic models. Yet, it must be granted that there are many kinds of knowledge and that 'models' can only in exceptional cases be expected to 
replace them, or even to outperform them. For the latter to happen, there must be a stable problem set on which to base the model and everyday life often, but not always, is fluctuating and full of unique problems. So, how $d o$ we acquire knowledge to assist us in everyday life in business or at home and what is the role of science?

\section{Everyday knowledge vs. science}

In this section, I briefly discuss the character of everyday knowledge and compare it to other belief systems without any reality contact on the one hand, science on the other. People 'know' about their environment in several ways. They may just feel that something is true, and have an intuition about it, without being able to explain why they feel that way, or they may base their perceptions and thoughts on something they have experienced. It is the latter alternative I will discuss here.

Every adult person knows some things such as

- we live on a large globe, a planet, which rotates around the sun

- water freezes to ice when the temperature is low enough

- all humans are mortal

- a week has seven days

- most humans strive for pleasure and try to avoid pain

- a certain friend is afraid of heights.

These are quite different examples. The first two refer to the physical world, the third is a biological fact, the fourth a social convention, the fifth a general psychological principle and the sixth an individual psychological fact. Science does not deny such statements, of course, and it has even historically contributed at least one of them, the first. For the other cases you need not trust science to believe in them. These are things that you can find out for yourself, by talking to other people and by observing nature. Knowledge acquired this way often is both trustworthy, necessary and used by everybody.

The sixth item illustrates a case of individual or local knowledge. Our lives are dependent on such knowledge to a large extent, yet it would not be useful at all in science, which must be based on generalities. Hence, there is perfectly good knowledge which is not scientific and which guides us in our everyday lives. Let us look a little further at a strategic aspect of such knowledge, causal attribution.

Science is superior to everyday life knowledge in two basic respects: it builds upon systematic empirical evidence and it organises such evidence in cumulative theoretical structures, which are subjected to continuous testing. But there are no clear boundaries between science and everyday life knowledge, and the latter is clearly superior to other forms of beliefs, such as paranoic delusions, phobias and magic, see Table 1 . 
Table 1 Various knowledge modes characterised by degree of theoretical elaboration and empirical basis

\begin{tabular}{|c|c|c|c|}
\hline \multirow[b]{2}{*}{ Empirical basis } & \multicolumn{3}{|c|}{ Conceptual elaboration } \\
\hline & Low & Medium & High \\
\hline Weak or none & Phobia & Mild delusions & $\begin{array}{l}\text { Paranoic delusions, } \\
\text { religion etc }\end{array}$ \\
\hline Medium & Magic & Everyday knowledge & $\begin{array}{l}\text { Science, theoretically } \\
\text { dominated }\end{array}$ \\
\hline Strong & $\begin{array}{l}\text { Science, empirically } \\
\text { dominated }\end{array}$ & $\begin{array}{l}\text { Science, building theory } \\
\text { on data }\end{array}$ & $\begin{array}{l}\text { Science, theoretical and } \\
\text { empirical }\end{array}$ \\
\hline
\end{tabular}

Everyday life knowledge is often the only realistic alternative since science may require too much in terms of time and other resources to be applied, or may simply fail to provide an answer. In ongoing social interaction, decisions may be called for without delay, and on the basis of incomplete and subtle cues. The actor cannot wait for scientific evidence on which to base his or her decisions, nor is it likely that it would be of much help to do so because scientific understanding of human and social phenomena is so incomplete and because the information that would be needed is often unavailable. Hence, the successful actor has no other good option than 'muddling through' (Lindblom, 1959), to try promising alternatives and to be ready to adjust tactics and strategy in the face of failure.

Phobia is a reaction almost totally devoid of any rational basis and it is recognised as such by the phobic him- or herself. Paranoic delusions have a similar rigidity but they are believed by the paranoic and they lend themselves to endless cognitive elaborations. Everyday knowledge can lead astray but it is connected with reality in a manner not common to phobic or paranoic notions. Therefore, one should not quickly dismiss public notions as phobic reactions (Drottz-Sjöberg and Persson, 1993). They may be incorrect because they are based on the insufficient evidence that we always have to base our common-sense beliefs on, as soon as we are not dealing with phenomena in a scientific manner, but they are not phobic.

Michotte (1954) performed classical studies of perceived causality. A very close temporal contiguity in the order 'first A then B' of two events virtually compels us to perceive that B was caused by A. ${ }^{5}$ Our perceptual apparatus is tuned to the discovery of causes and it organises our world view according to cause-effect relationships. We do not easily 'see' randomness, or its consequences. If purely random events are presented we see systematic patterns. In addition, when asked to produce or simulate random patterns of symbols people usually fail and produce systematic deviations from randomness. e.g., they produce too few long runs of one symbol. This could be explained by the famous gambler's fallacy effect: people believe that the likelihood of change increases the longer they have been exposed to a series of repetitions of one event (Bar-Hillel and Wagenaar, 1991).

Later work has been more concerned with inferred causality rather than directly perceived causality. Kahneman and Tversky have demonstrated that perception is affected by similarity (Tversky and Kahneman, 1974) and salience. If A and B are similar in some important manner and A preceded B, A may be regarded as the cause of B. If $\mathrm{A}$ is made salient by much media attention it is more likely to be regarded as the cause of events that followed it - especially if A is a very potent event, such as major 
technological disaster (Tversky and Kahneman, 1973). People also have a bias to perceive only one cause of an event, thereby greatly simplifying things, sometimes to the level of nonsense.

People sometimes encounter situations or problems in everyday life which calls for thinking and the formulation of constructs. It would be interesting to know something about how common such encounters are and under what conditions, external and internal, they occur. I next present some data bearing on this issue.

\section{When do we think?}

When do people think? There may be different reasons for thinking but surely an important one is a problem or a challenge that one has encountered.

Some time ago, I conducted together with Magneberg a project on action sampling (Magneberg, 1995; Sjöberg and Magneberg, 1990). Subjects carried a timer and were prompted, at randomly selected points in time, to report in writing what they were doing and to rate a number of dimensions pertinent to their ongoing activity. I did not do this with a random sample, for obvious reasons, but with small groups of volunteers from widely different professional lines of training, 152 in all. Each subject rated 35 actions, each of them in 29 variables.

There were 16 questions concerned with moods (Sjöberg et al., 1979) and emotions in the questionnaire; they were factor analysed. The four factors were interpreted as reflecting:

- $\quad$ shame

- involvement

- relaxation

- anger.

Factor scores were computed and standardised to a mean of 0 and a standard deviation of 1 . These data can be assumed to provide a fair assessment of the momentary emotional state of the subject.

The question I now pose is to what extent the subjects were facing a problem at the time of their response. One question asked them to rate if their ongoing action was hard or difficult. The distribution of responses to this question is given in Figure 1.

The figure shows that very few actions, only about $2 \%$, were rated as very difficult. Most actions were rated as easy. The distribution of difficulty of action was similar for on-the-job ratings between 9 am and $5 \mathrm{pm}$ and actions taking place in leisure time after 5 pm. 
The distortion of beliefs in the face of uncertainty

Figure 1 Distribution of ratings of action difficulty

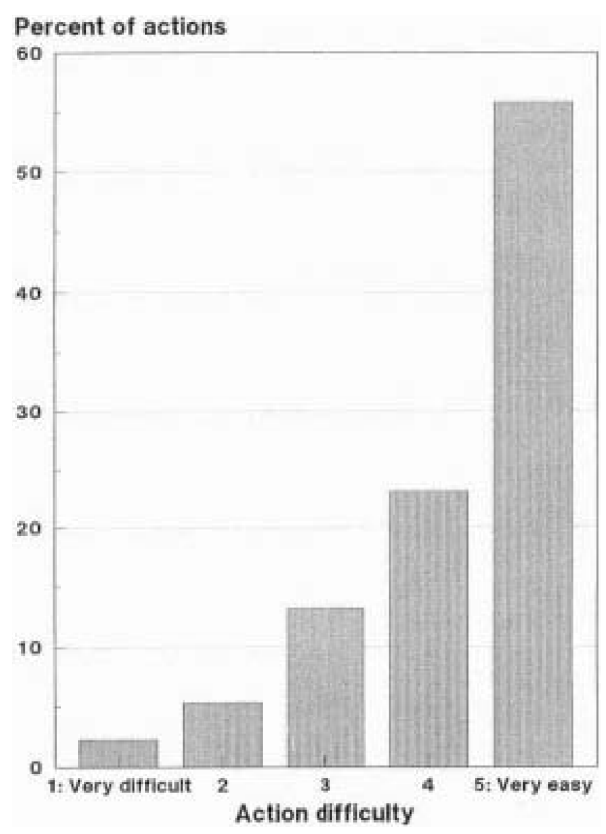

Looking at the emotional side of actions, it was found that difficult actions were high in shame, involvement and anger, low in relaxation. Easy actions were just the opposite. See Figure 2 which gives the mean factor scores for the extreme actions. The others were in between and are not shown in the figure.

Figure 2 Factor scores for easy and difficult actions

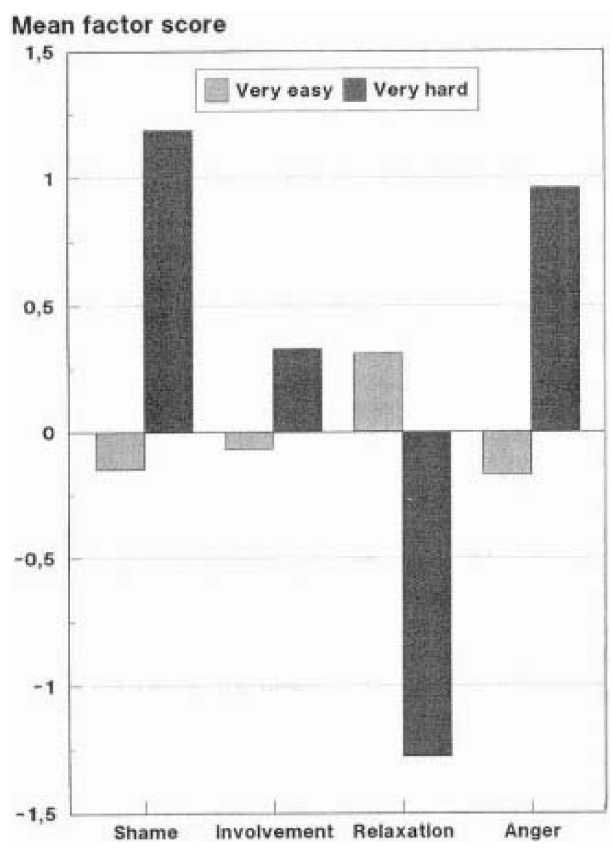


The present results convey an important message: demand for thought and hard judgement is rare, but when it occurs it tends to do so when we are in an unpleasant emotional state. This, in turn, makes the quality of thought even worse - difficulties of information processing are increased when emotions enter the picture (Cannon-Bowers and Salas, 1998; Persson, 1978).

Some more results from the action sampling study may be mentioned. Easy actions were rated as much more common than hard ones. This is in good agreement with the actual data, of course. The hard actions were, however, rated as more important than the easy ones. Yet, the hard actions were not very well liked, much less so than the easy ones.

Uncertainty is another aspect of action which can be analysed by the action sampling approach. One of the aspects rated was how certain the respondent felt. In Figure 3, I give the distributions of ratings of difficulty for actions rated in a state of either extreme uncertainty or extreme certainty.

Figure 3 Distributions of action difficulty for states of extreme uncertainty or certainty

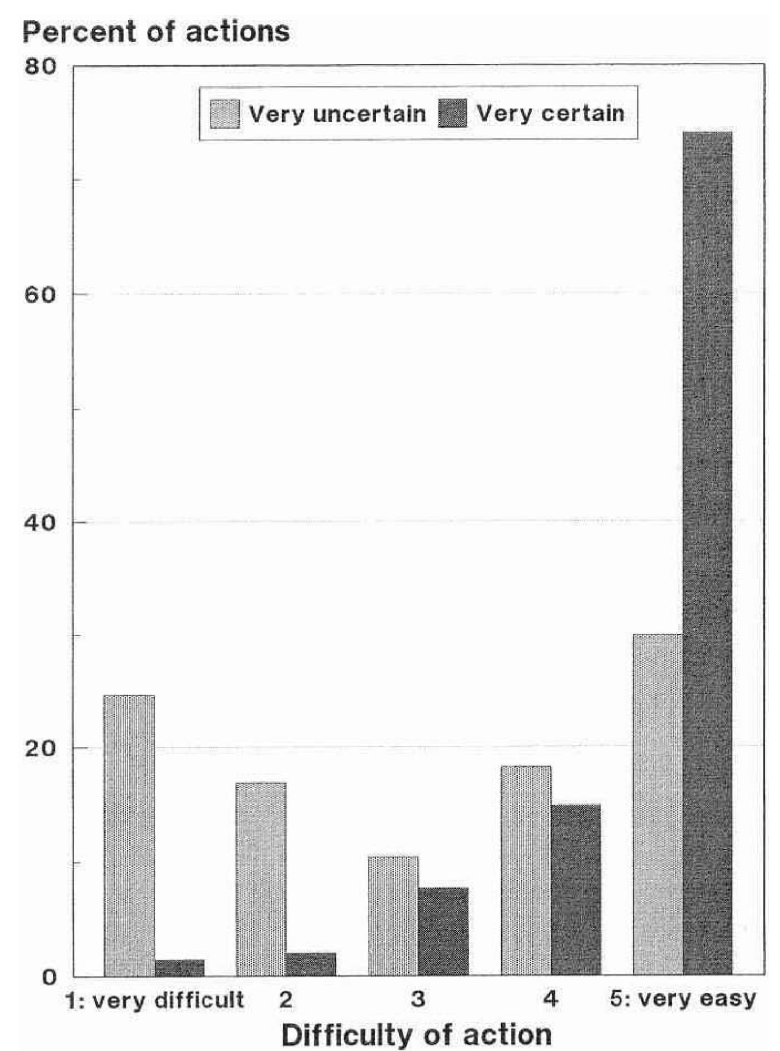

It is interesting to note that, for extremely uncertain states, respondents gave widely varying ratings of difficulty with many ratings of high levels of difficulty. For extremely certain states, they tended to rate the action as very easy. Further analysis showed that, in extreme uncertainty, the respondents also expected a negative outcome and that they had little influence over the situation. 
Although being in a state of extreme uncertainty is not quite the same as rating an outcome as uncertain the two are probably closely related, and the present results support that assumption.

Having encountered and hopefully solved a problem, or at least found some plausible course of action which would lead to acceptable results, you presumably tend to form a belief: "this is the way to do it". Or maybe you did not do all this yourself, but heard or read about someone who did it. We learn from models as well as from our own action (Bandura, 1986). The notions developed in this manner, based on experience, whether first hand or vicarious, tend to be victims of chance. How common are such problems? How can you judge if you do not have access to reliable statistics? Even if a problem is quite rare, the chance is good that you may have heard about a few cases. If it is a serious problem it may be quite salient in your mind and in the media. Hence, rare occurrences are used to form the basis of a concept of general relevance and the fact that they are quite rare is almost impossible to infer from casual exposure to single cases. Co-occurrences with various other events tend to be taken as a basis for causal attribution; people give most attention to positive co-occurrences and tend to forget about the three other possible cells of a four-field table (Smedslund, 1963).

Hence, people acquire knowledge in everyday life which is often quite correct, although not at all scientific. But this strategy may at times be very misleading, and it is hard for people to know when they should not 'trust what they can see with their own eyes'.

Organising one's knowledge is not easy. Quite frequently, we fall prey to the temptation to see what we want to see. In the next section, I present some support for that assertion.

\section{Values and beliefs}

Values and beliefs are logically distinct and should be kept apart. If anything, it should be expected that, in a natural social ecology, they should be negatively related because what is most attractive is also usually most expensive, or hardest to get. The probability that any one person will get the most attractive option is smaller the more attractive it is. Yet, in most data sets, when both probabilities and values are obtained for a number of stimuli, probabilities and values tend to be positively related (Sjöberg, 1982a, 1982b; Sjöberg and Biel, 1983).

As an example, I present data from a study of attitudes to membership in the European Union, carried out before the 1994 referendum on this issue in Sweden (Sjöberg, 1996). A large representative sample answered many questions about their attitudes and they also judged how likely each of 36 possible effects of membership were, and how likely the same effects were given that Sweden abstained from membership (beliefs). Furthermore, they judged how desirable the effects were (values). For each respondent, I computed the correlation between beliefs and values, for membership and for non membership. I also had data on the over-all attitude to membership on a seven-category bi-polar scale. I grouped the respondents according to attitude, and computed mean intra-individual correlations, see Figure 4. 
Figure 4 Belief-value correlations for different attitude levels and for membership and non-membership ratings

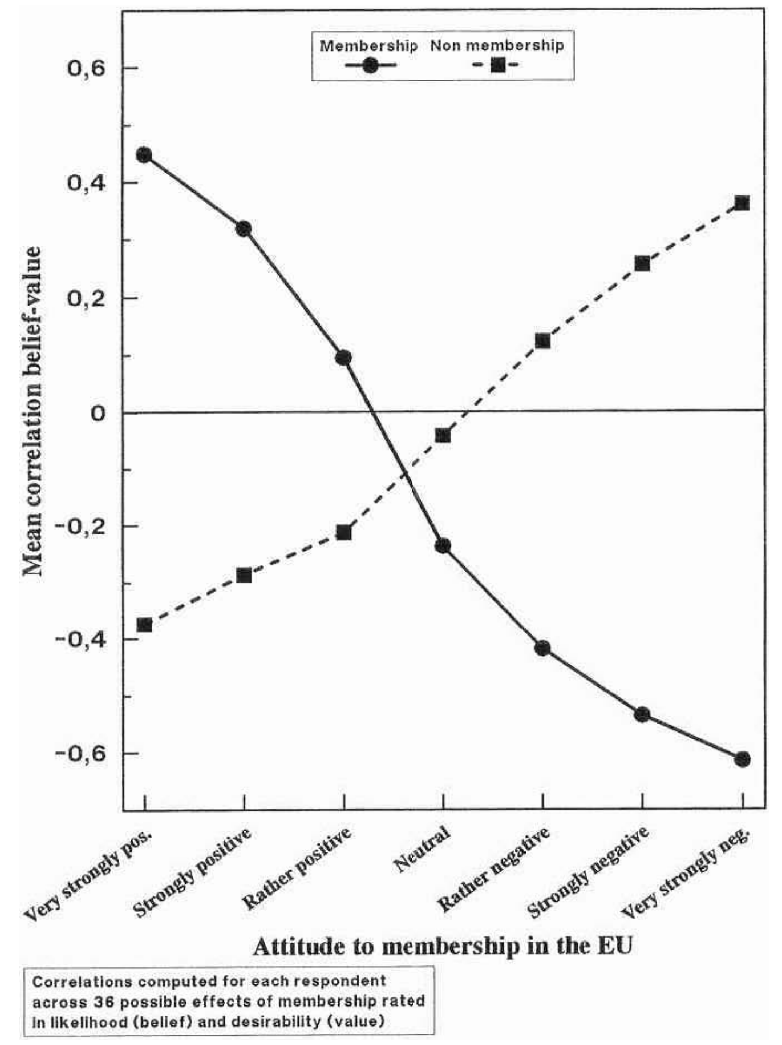

The figure illustrates how attitude is very strongly reflected in these correlations and that most respondents gave non-zero correlations - either positive or negative depending on their attitude and what belief they were assessing (membership or non membership).

These data are unusual in the sense that enough information was available for a very detailed analysis, but it is quite typical to find that beliefs and values are associated (Sjöberg, 1982b; Sjöberg and Biel, 1983; Wenglert and Rosén, 2000). Indeed, it has been suggested that beliefs and values really reflect the same underlying mental processes, or image (Sjöberg and Biel, 1983).

Such properties of beliefs and values are clearly an argument against traditional attitude scales of the type championed by Fishbein (Fishbein, 1963; Fishbein and Ajzen, 1975; Sjöberg, 1982a, 1999) and which have found very many applications in behavioural science generally (Sheppard et al., 1988). Montgomery and I have investigated a phenomenon we called double denial (Sjöberg and Montgomery, 1999) and which, simply speaking, means that people re-interpret values in more or less subtle ways when, in a debate, they are confronted with an opponents' arguments in terms of probabilities or values.

An example may make this idea more clear. Let us assume that you, a defence friend, are debating the Swedish defence budget with a convinced pacifist. A first line of argument would be to talk about probabilities, i.e., the probabilities that our country would be threatened by military intervention by a hostile power. This is seen as very 
unlikely by your opponent who vehemently denies that there is such a risk. However, you then switch to talking about how horrible it would be if our country were to be occupied. Your opponent, ordinarily also against the atrocities that might take place, now readily re-interprets the scenario and does not find it so terrible, after all, or can perhaps even see something positive in it.

Note that the opponent first denies the risk, then also denies that the risky events would be all that bad. In an expectation model of attitude, a negative event would always detract less if it is closer to the point of neutrality. We believe that what happens here is that people operate with two different value conceptions: one - implicit - when judging probabilities and another, adjusted when assessing values explicitly. They make no clear distinction between beliefs and values but use both as they see fit in a debate. A rational stance, such as that required by the expected value type of attitude models, requires values and beliefs to be independent. We find that they tend to interact and to be adjusted to the needs of rhetoric.

Behind such phenomena is, I believe, emotional reactions, or affect, which are elicited by the concepts or objects under considerations. Social objects tend to be emotionally provocative and we have quick reactions to them well before we start forming various cognitively loaded constructs about them (Zajonc, 1980). Our studies of person perception in bankers' interviews with credit applicants provide the same message about the pre-eminence of global person perception (Hedelin and Sjöberg, 1995).

I have, together with Derbaix, carried out studies of judgements of movie stars where preference and similarity judgements were elicited (Derbaix and Sjöberg, 1994; Derbaix et al., 1992; Sjöberg et al., 1987). In all these studies we found that there were more or less different bases underlying similarity and preference judgements, a finding which implies that multidimensional scaling methods assuming that similarities give information about a solid base for affective judgements, are of uncertain value. Of course, preferences can be scaled on their own without such supporting information, but the statistical problems then become quite difficult.

In social and political contexts, we consider concepts such as nuclear power and the 'risk' it has in the eyes of the public and experts (Sjöberg, 1998a). Risk perception of this kind is hardly to be understood as information processing at all. It is probably a reflection of underlying affect which is expressed in attitudes to the agents in society that are seen as responsible for generating the risks in question. In the case of nuclear power risks, it would be the nuclear power industry or the technology in abstract. It should also be stressed that 'risk' is often held to be more important than 'utility'; people simply do not wish to make an explicit trade-off between economics and health (Baron and Spranca, 1997; Sjöberg and Drottz-Sjöberg, 2001). Safety is not the opposite of risk; the matter is more complicated (and interesting) than that (Sjöberg, 2000a).

The exploitation of emotions and prejudice for rhetorical purposes was denounced already by Aristotle:

\footnotetext{
"The arousing of prejudice, pity, anger, and similar emotions has nothing to do with the essential facts, but is merely a personal appeal to the man who is judging the case. Consequently if the rules for trials which are now laid down some states - especially in well-governed states - were applied everywhere, such people would have nothing to say." Aristotle's Rhetoric, Book 1, translated by W.R. Roberts, 1954.
} 
The need to make a clear distinction between values and beliefs was as obvious to the classical philosopher as it is today. The 'unbearable flexibility of beliefs' makes it possible for people to believe just about anything, however flimsy, and to argue endlessly in its favour.

\section{Group and organisational phenomena}

Groups make many of the most important decisions in business and administration. There is little or no evidence that groups make more rational decisions than individuals, although they may, of course, be able to provide more information. The sum of all the information owned of the separate individuals involved in a group may be expected to be larger than the information processed by the group.

The pathologies of group decision making have been analysed by Janis's groupthink model (Aldag and Fuller, 1993; Esser and Lindoerfer, 1989; Janis, 1972; Park, 1990). Even if the details of the model can be debated, it does point to important and interesting phenomena. Analysing well-known disastrous group and organisational decisions may throw light on group pathologies and could maybe provide some ideas about how to avoid future disasters.

A book by Ortmark tries to do just that (Ortmark, 1996). He discusses well-known examples from business, i.e., Ivar Kreuger and Pehr Gyllenhammar. Kreuger was a financial tycoon in the 1920s who ended up killing himself when his vast empire had collapsed in the beginning of the 1930s. Gyllenhammar was for many years the admired and all-powerful president of Volvo until he was more or less forced to resign (in 1993) following intense criticism of his proposed Volvo-Renault merger. It is possible that some, or maybe even most, of these failures were due to lack of information of the main decisions makers who were supposedly surrounded by sycophantic yes-sayers. This is the thesis Ortmark argues and his proposed cure is the use of a Devil's Advocate whose role would require opposing the person in charge.

All this may sound plausible but it ignores the role of uncertainty. Was the collapse of the Kreuger empire really necessary and could it have been predicted? The problem was that only Kreuger himself had all the information and that he systematically misled people about his financial strength. Maybe the 'yes-sayers' should have questioned him, and a few did, but they could only do so on very meager evidence. As to Gyllenhammar, his basic notion that Volvo needed a partner was apparently sound (Volvo has later merged with Ford), but maybe his choice of partner was less than optimal and possibly the power relations envisioned after the merger would have been unfavourable to the Swedes. The latter aspect was only revealed to the public at a late stage. In hindsight, it is easy to see errors (Hawkins and Hastie, 1990) and make accusations about sycophant tendencies - when the events happen things are seldom so simple. In addition, many disastrous events in business or otherwise happen when very unexpected events have occurred, events that by definition were new and unfamiliar and therefore both unlikely and hard to deal with. There are few good strategies to deal with the uncommon and unlikely. 
A more recent example already mentioned, that of boo.com, affords information which leads to a somewhat less pessimistic picture of expert judgement. Boo.com was clearly given a very exaggerated valuation by investors in the initial phases leading up to the launching of its website in November, 1999. (The maximum valuation of this startup was $\$ 390$ million). The website was launched with a delay of five months, at great cost, and still by no means free of errors. ${ }^{6}$ Sales turned out to be only about a small fraction of the projected ones (Lindstedt, 2001). In spite of improved sales figures (partly due to a drastic price reduction and 'sale' in January 2000) they were still far below expectations in the beginning of 2000. At that point investors did react rationally, or so it seems. They fairly quickly backed out of their commitments, in spite of having to take heavy losses with regard to money already invested. The example illustrates rationality in a case when pertinent data (sales) are becoming available and wishful thinking before that point. The rationality of judgement was a function of availability of relevant information.

Yet, such a clearcut case may be exceptional. The present paper has demonstrated the high prevalence of unrealistic wishful thinking and other judgemental errors. It is natural to inquire into the possibility of improving things by means of education.

\section{Education: can thought habits be improved?}

At least on the surface, education is of paramount importance for just about everything. And it is more and more demanded on the job market. There are some obvious examples where education is necessary, such as in learning foreign languages and some elementary concepts of mathematics. Nobody denies that these are necessary skills. But for the rest, there is much to be doubted. Especially, do business men become better and more efficient from learning about how to make rational decisions? There is no proof that this is the case (Livingston, 1971).

The educational doctrine of formal discipline used to teach that learning something like Latin or Mathematics would make you think better (Haag, 1995; Thorndike and Woodworth, 1901). Very few have believed that for a century - see e.g., the failure of mathematics training to transfer, as described by Thorndike (1924) - and some recent work on the topic has failed to come up with strong transfer effects, even if they may occur under certain circumstances (Nisbett, 1987), such as awareness raising instructions (Berry, 1983). Expertise is overwhelmingly topic specific, and even at that, expertise per $s e$ is of doubtful value in many contexts. See the review by Cox (1997).

Organising an efficient educational system is by itself enormously difficult; see the sober account of a US attempt to do so by Branson (1998). Some teachers may be very much more efficient than the average teacher (Wright et al., 1997), but work procedures rather than individual errors are probably the important factor in organisational efficiency (Deming, 1986).

All this does not mean that employers are not right in recruiting their new employees from elite institutions. Those who are admitted to such institutions have been carefully selected from a very large number of applicants, and there is relatively strong predictive power in general mental ability, as witnessed by literally thousands of studies since the beginning of this century (Schmidt and Hunter, 1998). 


\section{Conclusions}

\section{Summing up}

What does it mean for an event to be a chance event? Are there such events? In this paper it is argued that the existence of such events has not been documented in social science. Yet, natural language often refers to chance events. Some examples of such events refer to gambling devices and similar equipment and, if they are fair, they exhibit many properties predicted from an assumption that they behave randomly. Reflection is sufficient to realise, however, that we do not believe that these events are truly random, they are merely modelled as such. In everyday life, there is an abundance of events often construed as chance events, on the basis that they emanate from the coincidence - e.g., spatially and temporally - of different and quite independent plans or intentions (often by different actors), but upon reflection these coincidences are also governed by causes and not truly random. They appear to be so, and they appear to be meaningless. The construal of such events as meaningful could be a sign of paranoia or religious fundamentalism. The opposite of a paranoid stance is that of fatalism. If events are truly random, nothing can be done to improve one's fate. However, there is a saying 'Trust in Allah, but tie up your camel'. The dark side of belief in chance and the pursuit of probabilistic thinking, often celebrated as a sophisticated way of thinking, is not tying up one's camel in good time, thus becoming the victim of life's all turbulent and indifferent forces.

We have seen that beliefs are affected by many factors, some of them clearly dysfunctional. Should we strive for a rationalistic belief system? This goal is probably impossible to reach, and most likely a chimera, even if it could be reached, because rationalism is defined in terms of beliefs and values that are themselves almost always highly subjective, even corrupt.

We have found that interest and other facets of intrinsic motivation are the most important determiners of job motivation (Sjöberg and Lind, 1994), together with involvement and commitment to job and firm (Björklund, 2001). Creativity is of paramount importance and it is closely related to interest. High levels of creativity are reached by those who have a burning interest in their tasks and who work on tasks they consider meaningful and very important (Bennis and Biederman, 1997). (They also must have the skills and the intellectual ability - and other abilities whenever needed - necessary for such accomplishments, of course).

Economic incentives is the traditional approach to increasing work motivation (Kanigel, 1998; Taylor, 1911/1998) but it is not used very much in Sweden, probably for ideological reasons. Money is spent on the work environment and various benefits, and that is in itself commendable, but not likely to lead to improved job performance. For example, some of Swedish automobile industry used job design according to the Hackman-Oldham approach (Hackman and Oldham, 1980), but that way they never came even close to Japanese productivity (Womack et al., 1990). Volvo's plants in Kalmar and Uddevalla were, in their time, much praised for their 'humanistic' job design principles. They are no longer operative. In the $1980 \mathrm{~s}$, it was for a while believed that this type of job design would create truly high motivation, but it could not counteract extreme levels of absenteeism as long as sick leave did not have any negative economic consequences for the employee. There is much evidence showing that job 
performance is unrelated or only weakly related to job satisfaction (Iaffaldano and Muchinsky, 1985; Sjöberg and Lind, 1994).

Finally, uncertainty should be considered in relation to belief dynamics. Uncertainty is a reflection of lack of knowledge. But to know that one is lacking in knowledge is itself knowledge. Uncertainty is a meta-belief, a belief about beliefs. Socrates liked to say that he knew more than all of the people in Athens because only he knew how little he knew. To deny uncertainty is most often a reflection of simplistic thinking. Even people who are $100 \%$ sure turn out to be wrong a large percentage of the time (Fischhoff et al., 1977). The step from an assumption or a hypothesis one makes up to a high degree of certainty, is often very small and almost unnoticeable. Support of a hypothesis is often easy to find, by selecting and interpreting information in a way which supports the preconceptions, or by conjuring up scenarios which have the same function. Hence, uncertainty as a phenomenological entity is perhaps not very trustworthy or even very interesting.

Yet, uncertainty is a crucial concept in the analysis of decisions. Our results from action sampling, described in the present paper, show that a high level of uncertainty is associated with negative expectations and the perception of restrictions on action. There were a few cases of 'uncertain optimism' but they were quite few. It seems reasonable to conclude, about uncertainty, that it tends to be a reflection of negative expectancy. When people expect technology to have as yet unknown effects, these effects are believed to be mainly negative (Sjöberg, 2001). Whether the distinction between uncertainty and negative expectancy really is useful depends of course of the thought habits people have and how they interpret these terms. So far, it seems to me that the distinction may be superfluous.

\section{Acknowledgments}

This is a study within the project Neglected risks (Bank of Sweden Tercentary Fund). I am grateful to professor Robyn Dawes and Dr. Patric Andersson for their comments on the manuscript.

\section{References}

Ackerman, P.L. and Heggestad, E.D. (1997) 'Intelligence, personality, and interests: evidence for overlapping traits', Psychological Bulletin, Vol. 121, pp.219-245.

Aldag, R.J. and Fuller, S.R. (1993) 'Beyond fiasco: a reappraisal of the groupthink phenomenon and a new model of group decision processes', Psychological Bulletin, Vol. 113, pp.533-552.

Anderson, N. (1996) A Functional Theory of Cognition, Mahwah, Erlbaum, NJ.

Babad, E. (1995) 'Can accurate knowledge reduce wishful thinking in voters' predictions of election outcomes', Journal of Psychology, Vol. 129, No. 3, pp.285-300.

Babad, E. (1997) 'Wishful thinking among voters: motivational and cognitive influences', International Journal of Public Opinion Research, Vol. 9, No. 2, pp.102-125.

Babad, E. and Katz, Y. (1991) 'Wishful thinking - against all odds', Journal of Applied Social Psychology, Vol. 21, No. 23, pp.1921-1938.

Bandura, A. (1986) Social Foundations of Thought and Action, Englewood-Cliffs, Prentice-Hall, NJ.

Bar-Hillel, M. and Wagenaar, W.A. (1991) 'Perception of randomness', Advances in Applied Mathematics, Vol. 12, pp.428-454. 
Baron, J. and Spranca, M. (1997) 'Protected values', Organizational Behaviour and Human Decision Processes, Vol. 70, No. 1, pp.1-16.

Bennis, W. and Biederman, P.W. (1997) Organizing Genius. The Secrets of Creative Collaboration, Reading, Perseus Books, Mass.

Berkeley, D. and Humphreys, P. (1982) 'Structuring decision problems and the bias heuristic', Acta Psychologica, Vol. 50, pp.20-52.

Berry, D.C. (1983) 'Metacognitive experience and transfer of logical reasoning', Quarterly Journal of Experimental Psychology, Vol. 35, No. 1, pp.39-49.

Björklund, C. (2001) Work Motivation - Studies of its Determinants and Outcomes, EFI, Stockholm.

Bonta, J., Law, M. and Hanson, K. (1998) 'The prediction of criminal and violent recidivism among mentally disordered offenders: a meta-analysisn', Psychological Bulletin, Vol. 123, pp.123-142.

Branson, R.K. (1998) 'Teaching-centered schooling has reached its upper limit: it doesn't get any better than this', Current Directions in Psychological Science, Vol. 7, pp.126-135.

Camerer, C.F. (2000) 'Prospect theory in the wild. Evidence from the field', in Kahneman, D. and Tversky, A. (Eds.): Choices, Values and Frames, Cambridge University Press, New York. pp.288-300.

Cannon-Bowers, J.A. and Salas, E. (1998) Making Decisions Under Stress, Implications for Individual and Team Training, American Psychological Association, Washington DC.

Cooksey, R.W. (1996) Judgment Analysis: Theory, Methods and Applications, Academic Press, San Diego, CA.

Cox, B.D. (1997) 'The rediscovery of the active learner in adaptive contexts: a developmental-historical analysis of transfer of training', Educational Psychologist, Vol. 32, No. 1, pp.41-55.

Cutler, B.L. and Penrod, S.D. (1995) Mistaken Identification, The Eyewitness, Psychology and the Law, Cambridge University Press, Cambridge.

Dawes, R.M. (1988) Rational Choice in an Uncertain World, San Diego, Harcourt Brace Jovanovich, CA.

Dawes, R.M. (1994) House of Cards. Psychology and Psychotherapy Built on Myth, The Free Press, New York.

Delmar, F. (1996) Entrepreneurial Behaviour and Business Performance, EFI, Stockholm.

Deming, W.E. (1986) Out of the Crisis, Cambridge, MIT, MA.

Derbaix, C. and Sjöberg, L. (1994) 'Movie stars in space: a comparison of preference and similarity judgments', International Journal of Marketing Research, Vol. 11, pp.261-274.

Derbaix, C., Sjöberg, L. and Lefebre, B. (1992) 'Etude comparative des jugements cognitifs et affectifs émis vis-a-vis d'acteurs et d'actrices de cinéma', Actes de l'Association Française du Marketing, Vol. 8, pp.165-183.

Douglas, M. and Wildavsky, A. (1982) Risk and Culture, Berkeley, University of California Press, CA.

Drottz-Sjöberg, B-M. and Persson, L. (1993) 'Public reaction to radiation: fear, anxiety or phobia?', Health Physics, Vol. 64, pp.223-231.

Eagley, A.H. and Chaiken, S. (1993) The Psychology of Attitudes, Fort Worth, Harcourt Brace Jovanovich, TX.

Ekman, P. and O’Sullivan, M. (1991) 'Who can catch a liar?', American Psychologist, Vol. 46, pp.913-920.

Ericsson, K.A. and Charness, N. (1994) 'Expert performance. Its structure and acquisition', American Psychologist, Vol. 49, pp.725-747.

Ericsson, K.A. and Smith, J. (Eds.) (1991) Toward a General Theory of Expertise, Cambridge University Press, Cambridge. 
Esser, J.K. and Lindoerfer, J.S. (1989) 'Groupthink and the space shuttle challenger disaster: Toward a quantitative case analysis', Journal of Behavioural Decision Making, Vol. 2, pp.167-177.

Fischhoff, B., Slovic, P. and Lichtenstein, S. (1977) 'Knowing with certainty: the appropriateness of extreme confidence', Journal of Experimental Psychology: Human Perception and Performance, Vol. 3, pp.552-564.

Fishbein, M. (1963) 'An investigation of the relationships between beliefs about an object', Human Relations, Vol. 16, pp.233-240.

Fishbein, M. and Ajzen, I. (1975) Belief, Attitude, Intention and Behaviour: An Introduction to Theory and Research, Reading, Addison-Wesley, MA.

Furusten, S. (1996) Den Populära Managementkulturen - Om Produktion Och Spridning Av Populär 'Kunskap' Om Företagsledning, Nerenius and Santérus, Stockholm.

Garb, H.N. (1998) Studying the Clinician: Judgment Research and Psychological Assessment, APA, Washington DC.

Gigerenzer, G. (1996) 'The psychology of good judgment: frequency formats and simple algorithms', Medical Decision Making, Vol. 16, pp.273-280.

Gigerenzer, G., Hoffrage, U. and Kleinbolting, H. (1991) Probabilistic Mental Models: A Brunswikian Theory of Confidence, Vol. 98, pp.506-528.

Gilovich, T. (1991). How We Know What Isn't So: The Fallibility of Human Reason in Everyday Life, The Free Press, New York.

Gilovich, T. (1997) 'Some systematic biases of everyday judgment', Skeptical Inquirer, Vol. 21, No. 2, pp.31-35.

Goldberg, L.R. (1970) 'Man versus model of man: a rationale plus some evidence for a method of improving clinical inferences', Psychological Bulletin, Vol. 73, pp.422-432.

Grove, W.M. and Meehl, P.E. (1996) 'Comparative efficiency of informal (subjective, impressionistic) and formal (mechanical, algorithmic) prediction procedures: the clinical-statistical controversy', Psychology, Public Policy and Law, Vol. 2, pp.293-323.

Grove, W.M., Zald, D.H., Lebow, B.S., Snitz, B.E. and Nelson, C.E. (2000) 'Clinical vs. mechanical prediction: a meta-analysis', Psychological Assessment, Vol. 12, pp.19-30.

Haag, L. (1995) 'Effects of Latin teaching', Psychologie in Erziehung und Unterricht, Vol. 42, pp.245-254.

Hackman, J.R. and Oldham, G.R. (1980) 'Motivation through the design of work', in Hackman, J.R. and Oldham, G.R. (Eds.): Work Redesign, Reading, Addison-Wesley, MA, pp.71-94.

Hatton, R.M. (1968) Charles XII of Sweden, Weidenfeld and Nicolson, London.

Hawkins, S.A. and Hastie, R. (1990) 'Hindsight: biased judgments of past events after the outcomes are known', Psychological Bulletin, Vol. 127, pp.311-327.

Hedelin, L. and Sjöberg, L. (1995) 'Bankers' judgments of loan applicants in regard to new ventures', in Green, B. (Ed.): Risky Business, Risk Research Group, University of Stockholm, Stockholm, pp.67-94.

Iaffaldano, M.T. and Muchinsky, P.M. (1985) 'Job satisfaction and job performance: a meta-analysis', Psychological Bulletin, Vol. 97, pp.251-273.

Janis, I.L. (1972) Victims of Groupthink, Houghton Mifflin, Boston.

Kahneman, D. (2000) 'New challenges to the rationality assumption', in Kahneman, D. and Tversky, A. (Eds.): Choices, Values and Frames, Cambridge University Press, New York, pp.758-774.

Kahneman, D. and Tversky, A. (1984) 'Choices, values, and frames', American Psychologist, Vol. 39, pp.341-350.

Kanigel, R. (1998) The One Best Way: Frederick Winslow Taylor and the Enigma of Efficiency, Viking, New York. 
Lefcourt, H.M. (1976) Locus of Control: Current Trends in Theory and Research, Potomac, Erlbaum, MD.

Liljegren, B. (2000) Karl XII: En Biografi, Historiska media, Lund.

Lindblom, C.E. (1959) 'The science of 'muddling through', Public Administration Review, Vol. 19, pp.79-88.

Lindeman, M. (1998) 'Motivation, cognition and pseudoscience', Scandinavian Journal of Psychology, Vol. 39, pp.257-265.

Lindstedt, G. (2001) Boo.com Och IT-Bubblan Som Sprack, Bokförlaget DN, Stockholm.

Livingston, J.S. (1971) 'Myth of the well-educated manager', Harvard Business Review, Vol. 79, pp.79-89.

Magneberg, R. (1995) An Evaluation of the Method of Random Action Sampling, Unpublished $\mathrm{PhD}$, Stockholm School of Economics.

Malmsten, E., Portanger, E. and Drazin, C. (2001) Boo Hoo. A Dot.Com Story from Concept to Catastrophe, Random House, London.

Manove, M. and Padilla, A.J. (1999) 'Banking (conservatively) with optimists' Rand Journal of Economics, Vol. 30, No. 2, pp.324-350.

Marrs, J. (1989) Crossfire. The Plot that Killed Kennedy, Carroll and Graf, New York.

McNeil, B.J., Pauker, S.G., Sox, H.C. and Tversky, A. (1982) 'On the elicitation of preferences for alternative therapies', New England Journal of Medicine, Vol. 306, pp.1259-1262.

Meehl, P.E. (1954) Clinical versus Statistical Prediction: A Theoretical Analysis and a Review of the Evidence, University of Minnesota Press, Minneapolis.

Mele, A.R. (1994) 'Self-control and belief', Philosophical Psychology, Vol. 7, pp.419-435.

Mele, A.R. (1997) 'Real self-deception', Behavioural and Brain Sciences, Vol. 20, No. 1, p.91.

Metcalfe, J. (1998) 'Cognitive optimism: self-deception or memory-based processing heuristics?', Personality and Social Psychology Review, Vol. 2, No. 2, pp.100-110.

Michotte, A. (1954) La Perception De La Causalité, Publications Universitaires de Louvain, Louvain.

Miller, G.A. (1956) 'The magical number seven, plus or minus two: some limits on our capacity for processing information', Psychological Review, Vol. 63, pp.81-97.

Neisser, U. and Harsch, N. (1992) 'Phantom flashbulbs: false recollections of hearing the news about Challenger', in Winograd, E. and Neisser, U. (Eds.): Affect and Accuracy in Recall: Studies of 'Flashbulb memories', Cambridge University Press, Cambridge.

Nisbett, R.E. (1987) 'Teaching reasoning', Science, Vol. 238, pp.625-631.

Ortmark, Å. (1996) Ja-Sägarna, Wahlström and Widstrand, Stockholm.

Park, W-W. (1990) 'A review of research on groupthink', Journal of Behaviural Decision Making, Vol. 3, pp.229-246.

Persson, L-O. (1978) The Influence of Emotions on Information Processing, Göteborg Psychological Reports 8, 7, Department of Psychology, Göteborg.

Ramsey, F.P. (Ed.) (1931) The Foundations of Mathematics and other Logical Essays, K. Paul, Trench, Trubner, London.

Ross, M. and Fletcher, G.J.O. (1985) 'Attribution and social perception', in Lindzey, G. and Aronson, E. (Eds.): Handbook of Social Psychology, Special Fields and Applications, Random House, New York, Vol. II, pp.73-122.

Ruscio, J. (2002) ‘The emptiness of holism', Skeptical Inquirer, Vol. 26, pp.46-50.

Sa, W.C., West, R.F. and Stanovich, K.E. (1999) 'The domain specificity and generality of belief bias: Searching for a generalizable critical thinking skill', Journal of Educational Psychology, Vol. 91, pp.497-510. 
Schacter, D.L. (1999) 'The seven sins of memory: insights from psychology and cognitive neuroscience', American Psychologist, Vol. 54, pp.182-203.

Schmidt, F.L. and Hunter, J.E. (1998) 'The validity and utility of selection methods in personnel psychology: practical and theoretical implications of 85 years of research findings', Psychological Bulletin, Vol. 124, pp.262-274.

Shanteau, J. (1988) 'Psychological characteristics and strategies of expert decision makers', Acta Psychologica, Vol. 68, pp.203-215.

Shanteau, J. (1992a) 'Competence in experts: the role of task characteristics', Organizational Behaviour and Human Decision Processes, Vol. 53, pp.252-266.

Shanteau, J. (1992b) 'How much information does an expert use? Is it relevant?' Acta Psychologica, Vol. 81, pp.75-86.

Shanteau, J. and Stewart, T.R. (1992) 'Why study expert decision making? Some historical perspectives and comments', Organizational Behaviour and Human Decision Processes, Vol. 53, pp.95-106.

Shefrin, H. (1999) Beyond Greed and Fear: Understanding Behavioural Finance and the Psychology of Investing, Oxford University Press, New York.

Sheppard, B.H., Hartwick, J. and Warshaw, P.R. (1988) 'The theory of reasoned action: a meta-analysis of past research with recommendations for modifications and future research', Journal of Consumer Research, Vol. 15, pp.325-343.

Shiller, R. (2000) Irrational Exuberance, Princeton University Press, Princeton NJ.

Simons, R. (1999) 'How risky is your company?', Harvard Business Review, Vol. 77, No. 3, pp.85-94.

Sjöberg, L. (1979) 'Strength of belief and risk', Policy Sciences, Vol. 11, pp.39-57.

Sjöberg, L. (1980) 'Volitional problems in carrying through a difficult decision', Acta Psychologica, Vol. 45, pp.123-132.

Sjöberg, L. (1982a) 'Attitude-behaviour correlation, social desirability and perceived diagnostic value', British Journal of Social Psychology, Vol. 21, pp.288-292.

Sjöberg, L. (1982b) 'Beliefs and values as components of attitudes', in Wegener, B. (Ed.): Social Psychophysics, Hillsdale, Erlbaum, NJ, pp.199-218.

Sjöberg, L. (1996). Riskuppfattning Och Inställning Till Svenskt Medlemskap $i$ EU. (Risk Perception and Attitude to Swedish Membership in the EU), Styrelsen för Psykologiskt Försvar, Stockholm.

Sjöberg, L. (1997) Studieintresse Och Studiemotivation, Svenska Arbetsgivareföreningen och Institutet för individanpassad skola, Stockholm.

Sjöberg, L. (1998a) 'Risk perception: experts and the public', European Psychologist, Vol. 3, pp.1-13.

Sjöberg, L. (1998b) 'Will and success - individual and national', in Sjöberg, L., Bagozzi, R. and Ingvar, D. (Eds.): Will and Economic Behaviour, EFI, Stockholm, pp.85-119.

Sjöberg, L. (1999) 'Attitudes, opinions and values: models and dynamics', in Juslin, P. and Montgomery, H. (Eds.): Judgment and Decision Making: Neo-Brunswikian and Process-Tracing Approaches, Mahwah, Erlbaum, NJ, pp.219-242.

Sjöberg, L. (2000a) Asymmetry of Risk and Safety, Research report, Center for Risk Research, Stockholm School of Economics, Stockholm.

Sjöberg, L. (2000b) 'Factors in risk perception', Risk Analysis, Vol. 20, pp.1-11.

Sjöberg, L. (2001) 'Limits of knowledge and the limited importance of trust', Risk Analysis, Vol. 21, No. 1, pp.189-198.

Sjöberg, L. (2002a) 'Frestelser minerar börsens psykologiska landskap, Temptations undermine the psychological landscape of the stock exchange', Svenska Dagbladet, January 9, p.9.

Sjöberg, L. (2002b) 'Vad kan vi lära av en sprucken bubbla? (What can we learn from a burst bubble?)', Ekonomisk Debatt, Vol. 30, pp.271-275. 
Sjöberg, L. and af Wåhlberg, A. (2002) 'Risk perception and new age beliefs', Risk Analysis, Vol. 22, No. 4, pp.751-764.

Sjöberg, L. and Biel, A. (1983) 'Mood and belief-value correlation', Acta Psychologica, Vol. 53, pp. $253-270$.

Sjöberg, L. and Dahlstrand, U. (1987) 'Subject matter attributes and study interests in post-secondary education', Higher Education, Vol. 16, pp.357-372.

Sjöberg, L. and Drottz-Sjöberg, B-M. (2001) 'Fairness, risk and risk tolerance in the siting of a nuclear waste repository', Journal of Risk Research, Vol. 4, No. 1, pp.75-102.

Sjöberg, L. and Lind, F. (1994) Arbetsmotivation I En Krisekonomi: En Studie Av Prognosfaktorer. Work Motivation in a Crisis Economy: A Study of Prognostic Variables, Studier i ekonomisk psykologi 121, Institutionen för ekonomisk psykologi, Handelshögskolan i Stockholm.

Sjöberg, L. and Magneberg, R. (1990) 'Action and emotion in everyday life', Scandinavian Journal of Psychology, Vol. 31, pp.9-27.

Sjöberg, L. and Montgomery, H. (1999) 'Double denial in attitude formation', Journal of Applied Social Psychology, Vol. 29, pp.606-621.

Sjöberg, L. and Pirie, J.G. (1999a) 'Cases in project success and failure', Paper presented at the Third International Stockholm Seminar on Risk Behaviour and Risk Management, University of Stockholm, Stockholm.

Sjöberg, L. and Pirie, J.G. (1999b) 'Project success or failure - contributing factors', Paper presented at the Third International Stockholm Seminar on Risk Behaviour and Risk Management, Stockholm.

Sjöberg, L., Derbaix, C. and Jansson, B. (1987) 'Preference and similarity: affective and cognitive judgment?', Scandinavian Journal of Psychology, Vol. 28, pp.56-68.

Sjöberg, L., Svensson, E. and Persson, L-O. (1979) 'The measurement of mood', Scandinavian Journal of Psychology, Vol. 20, pp.1-18.

Skinner, B.F. (1948) 'Superstition' in the pigeon', Journal of Experimental Psychology, Vol. 38, pp.168-172.

Smedslund, J. (1963) 'The concept of correlation in adults', Scandinavian Journal of Psychology, Vol. 4, pp.165-173.

Taylor, F.W. (1911/1998) The Principles of Scientific Management, Dover Publications, New York.

Taylor, S.E. and Brown, J.D. (1988) 'Illusion and well-being: a social psychological perspective on mental health', Psychological Bulletin, Vol. 103, pp.193-210.

Thorndike, E.L. (1924) 'Mental discipline in high school studies', Journal of Educational Psychology, Vol. 15, No. 1, pp.1-22.

Thorndike, E.L. and Woodworth, R.S. (1901) 'The influence of improvement in one mental function upon the efficiency of other functions, I', Psychological Review, Vol. 8, pp.247-261.

Tversky, A. and Kahneman, D. (1973) 'Availability: a heuristic for judging frequency and probability', Cognitive Psychology, Vol. 4, pp.207-232.

Tversky, A. and Kahneman, D. (1974) 'Judgment under uncertainty: heuristics and biases', Science, Vol. 185, pp.1124-1131.

Vinchur, A.J., Schippman, J.S., Switzer, I.F.S. and Roth, P.L. (1998) 'A meta-analytic review of predictors of job performance for salespeople', Journal of Applied Psychology, Vol. 83, pp.586-597.

Vyse, S.A. (1997) Believing in Magic, The Psychology of Superstition, Oxford University Press, New York.

Wärneryd, K-E. (2001) Stock-Market Psychologyi, How People Value and Trade Stocks, Cheltenham, Edward Elgar, UK.

Wenglert, L. and Rosén, A-S. (2000) 'Measuring optimism-pessimism from beliefs about future events', Personality and Individual Differences, Vol. 28, pp.717-728. 
Womack, J.P., Jones, D.T. and Roos, D. (1990) The Machine that Changed the World, The Story of Lean Production, Harper, New York.

Wright, S.P., Horn, S.P. and Sanders, W.L. (1997) 'Teacher and classroom context effects on student achievement: implications for teacher evaluation', Personnel Evaluation in Education, Vol. 11, pp.57-67.

Zajonc, R.B. (1980) 'Feeling and thinking - preferences need no inferences', American Psychologist, Vol. 35, pp.151-175.

\section{Notes}

${ }^{1}$ There is little point in basing an argument in social science on epistemological principles derived from quantum physics. For example, Heisenberg's uncertainty principle has frequently been invoked to argue that observers may affect what they observe, a point that is surely trivially true in social science and needs no backing from theoretical physics.

${ }^{2}$ In fact, Prince Fredrik was destined to become Fredrik I of Sweden and to succeed Charles, after a brief interlude during which Charles's sister served as Regent. Charles was not married and had no children.

${ }^{3}$ This is a rather speculative functional interpretation of the judgment processes observed. There is no proof that they exist because of a need to simplify cognitive tasks.

${ }^{4}$ A fuller discussion is available elsewhere (Sjöberg, 1998b).

${ }^{5}$ Such perception is often illusory, as when I push a light button in my home at same time as there is some explosive noise from the street outside.

${ }^{6} \mathrm{~A}$ few examples may suffice. Mac users could not use the site, and neither could for some reason users in Italy. It took 4 minutes to download the homepage. 